\title{
Violence, Aggression and Insecurity in the Niger Delta of Nigeria: An Exploratory Study of the Militancy in the Region
}

\author{
Gilbert Enyidah-OkeyOrdu, Ph.D. \\ Department of Criminology and Security Studies \\ Faulty of Management and Social Studies \\ Federal University Ndufu-Alike Ikwo, P.M.B. 1010, \\ Ebonyi State, Nigeria
}

\begin{abstract}
The Niger Delta region is endowed with oil and natural gas, and contributes enormously to the building of Nigerian economy. With the Niger Delta's economic contributions, Nigeria rewarded the people in the region with environmental pollution, abject poverty and unemployment. While the oil companies exploited and marginalized the Niger Delta region, the militants emerged with violence and aggression to disrupt oil production, installations and allied facilities in an effort to compel the federal government and oil companies to meet their demands for human capacity building and general infrastructural developments as well as compensations for the widespread exploitations and environmental pollutions that are going on in this region. The failures of the oil companies and the federal government of Nigeria to comply with the demands of the militants fueled violence, aggression and insecurity in the region. This study use secondary data to examine the critical nature of the Niger Delta militants' violence and aggression in Nigeria and its effects on the country's national economy. This paper concludes that the federal government of Nigeria, with the support of the oil companies, should genuinely address the demands of the Niger Delta people and strictly adhere to international environmental standards as regards land and water preservation.
\end{abstract}

Keywords: Violence, Aggression, Insecurity, Militancy, Niger Delta, Nigeria.

\section{INTRODUCTION}

Nigeria is the largest producer of oil and natural gas in Africa (Oronta, 2001; Okaba, 2005; Nwogwugwu, Alao \& Egwuonwu, 2012). The majority of the oil and natural gas are produced in the Niger Delta States. The Niger Delta is an important region because of its 'oil' and 'natural gas' deposits. The NDDC ACT (2000) [Niger Delta Development Commission] recognizes nine states as the members of the Niger Delta region. These states include: Abia, Akwa-Ibom, Bayelsa, Cross River, Delta, Edo, Imo, Ondo and Rivers. However, the core Niger Delta Basin are Bayelsa, Delta and Rivers States. Kimiebi (2010) indicated that the core states of Niger Delta are "geographically characterized predominantly to an extent with deltaic features" (p. 109).The map below shows the location of the nine states that made up the Niger Delta region in Southern Nigeria. 


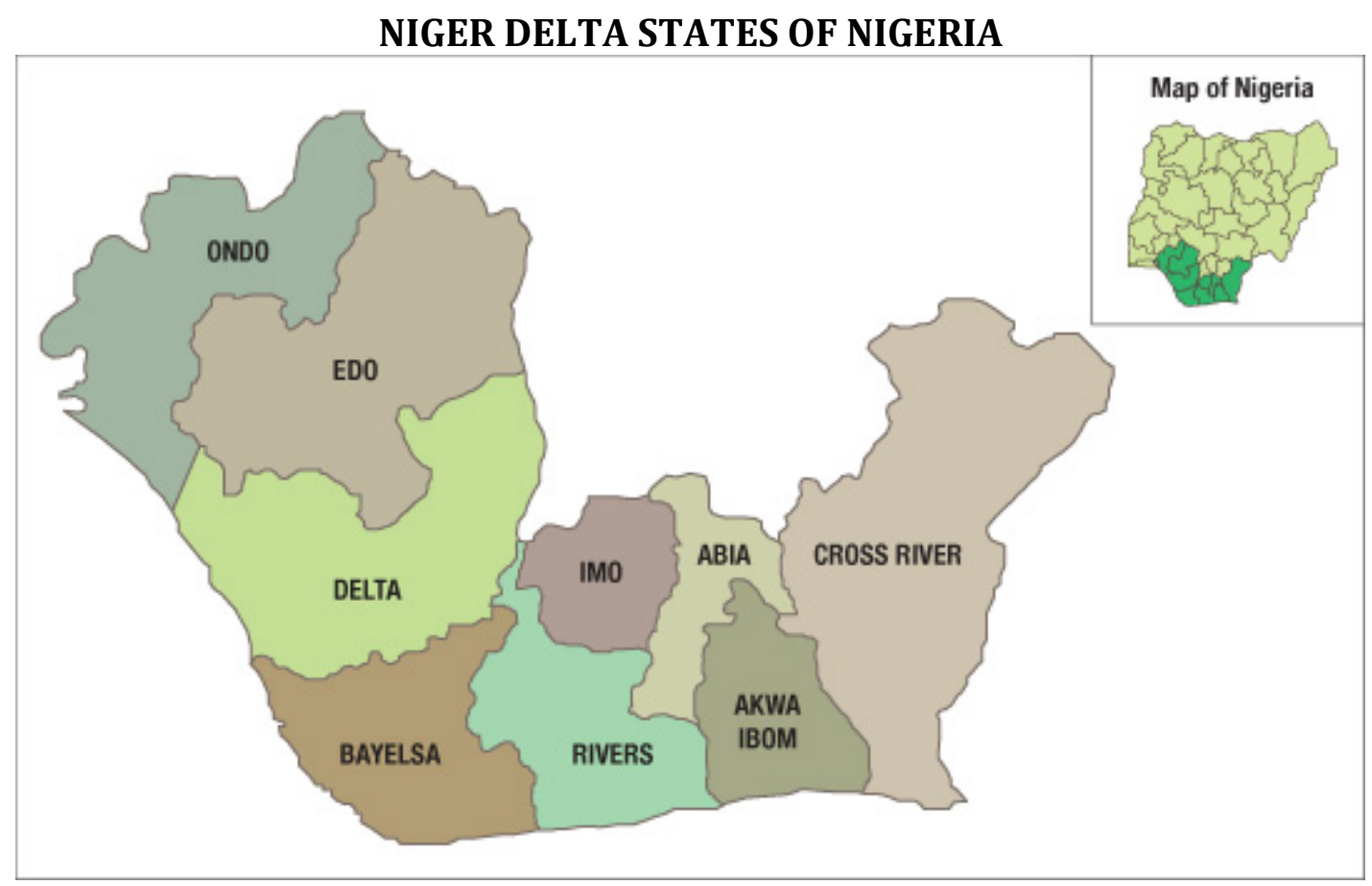

Source: Niger Delta Region of Nigeria (www.google.com)

These natural resources are the life blood of the Nigerian's economy (Kimiebi, 2010).While oil and natural gas deposits are in extraordinarily abundant in Niger Delta, Nigeria has failed to translate those natural resources to communal prosperity and infrastructural development in the appeasements of the regional residents. What we have seen in the last decades have been "massive environmental degradation and political and economic marginalization" (Nwogwugwu et al., 2012 p. 23). The government violently and aggressively repressed the peaceful dissent exemplified by Ken Saro-Wiwa saga, thereby creating serious spurious flames of political and economic disaster for the country.

The Niger Delta agitations have not received maximum rewards over the years and thus creating a prolonged dialog that is taking toll on the oil and natural gas establishments in the nation. The deliberate negligence of the federal government and the oil companies induced the emergence of the militants in the region. Whereas the militants adopted violence and terror against the federal government and oil companies [their oil pipeline establishments], kidnapping and vandalism became amplified in the core Niger Delta states of Bayelsa, Delta and Rivers. The Niger Delta militants [exploiting the federal government use of repressive and abusive powers], perpetuate violent and terroristic attacks on oil and natural gas infrastructures, as well as make the region politically ungovernable and economically destabilized. Vandalizing the oil pipelines affects the oil production and endangers the lives and property of employees and the residents in the affected areas. Apparently, the national economy plunges and depicts the nation that depends on the oil [as its life blood of survival] into economic crisis (Ubhenin \& Enabunene, 2011).

The activities of the oil companies and failure of the federal government to properly compensate the communities from the oil zones subscribe continuous violence, aggression and general crisis in the region. Therefore, the militants continue to "negatively impact the monolithic Nigerian economy as it has affected the inflow of foreign direct investment which is needed to achieve economic growth and development" (Nwogwugwu et al., 2012 p. 24). A vast majority of the violence and aggression between Nigeria and militants in the Niger Delta region 
are induced by the federal government's authoritarianism, wrong policies [on equitable share of oil revenue], decades of injustice meted out to ethnic minority groups and repressive behaviours. As long as the federal government and the oil companies continue to give deaf ears to the demands of the Niger Delta regions, the country will continue to waste its revenue in seeking for illusionary sense of security as the nation is invaded by vandalism, murder, kidnapping, armed robbery and other criminal activities. Adegbami (2013) asserted thus:

Unfortunately, ordinary citizens as well as the nation's economic resources are at the receiving end of this wanton destruction. The series of bombings and killings in the north; kidnapping and armed robbery attack in the south; political and economic related assassinations as well as the politically-influenced communal wars has become a multi-hydra headed monster which security agents in Nigeria appear incapable of handling (p. 8).

In fact, those networks of criminal activities have crippled government operations and handicapped the fundamental human rights, which are imbedded in the right to life, liberty and pursuance of happiness. Unfortunately, these rights have been invaded by divergent of heinous criminal activities with weak state security establishments. The various forms of criminality in this country can be arrested when the federal government lays down their arms against the militants and respect the rights and dignity of the Niger Delta people and voices of peace and tranquility in the nation.

\section{THEORETICAL FRAMEWORK}

In our theoretical thoughts, we applied postmodernist philosophy which deals with misinterpretation of actions and behaviours of people in society. A situation we refer to as antirealism, whereby the reality of an issue becomes a subjective construction of human criticism. When people disagree with the state, "the government often calls them names such as "political dissidents", "traitors," "revolutionaries", "criminals", "freedom fighters" and "terrorists" (Thio, 2004 p. 51a). "But the so-called deviants-dissidents, revolutionaries, and freedom fightersrefer to themselves as concerned citizens battling a corrupt government" (p. 51b). Postmodernist philosophy is also a deconstructionism, which tells us why some people form groups as militants [oppositionists] to break-up, tear-down, destroy and challenge the unconventional methods with violence and aggression in order to institute conventional methods [i.e. the way things should be done]. This reflects the battle between the federal government of Nigeria and the militant groups in the Niger Delta regions. The historical reality of injustice meted out against the Niger Delta people by Nigeria government and the oil companies remain a shadow of fact.

However, there are a number of historical studies in both criminological and sociological literature that explore social facts and dynamics to explain contemporary phenomena in terms of the origins of their historical developments. For instance, Erikson (1966) used historical analysis to elucidate how danger could hunt a person who virtually ignores the warning signals. Piven and Cloward (1971) adopted historical approach to analyze welfare system in the United States since after the depression. Other scholars such as Williamson, Karp and Dalphin (1977) and Klegon (1981) adopted historical approaches in their explanations of various phenomena in social sciences, and some historical studies tend to be qualitative or humanistic, but there is also an increased use of quantitative analysis in historical studies (Bailey, 1982). Ake (1981) stated that the major advantage of historical approach is that it leads us to the relationships between various social phenomena by exposing a variety of substructures and superstructures of all variables. Historical legendary moves us into the nucleus of the origins of the problems, the policies and malfeasances. 
This study therefore adopts historical analysis in theorizing the causal factors of the emergence of the Niger Delta militants' violence and aggression, the monopolistic-negligent behaviour of the federal government and oil companies' exploitative behaviours in this region. Akpan (2010) pointed out that the historical establishment of oil companies in the Niger Delta region began with Shell-BP in 1956 when it discovered Petroleum in the region. Since that period, so many major oil companies flooded the region. Such oil companies include "Mobil Producing Nigeria Ltd, Chevron Nigeria Ltd, Nigeria Agip Oil Company, Elf Petroleum Ltd, and Texaco Overseas (Nigeria) Petroleum Company" (Akpan, 2010 p. 36). The Niger Delta became so important that Nigeria's economy depends on petroleum resources from the region. Despite the historic reservoir of oil and natural gas in the Niger Delta, systemic injustice of marginalization and experiences of the Nigerian-Biafra civil war, the Nigerian government has still not effectively found a solid ground for resolving militant's agitations. Instead, we see a nation deepened in human insecurity and national economic disaster, which in reality, is like a nation inhibiting citizens struggling for freedom. The militants are agitating to change the status quo and this has affected Nigeria's economic growth.

\section{RESULTS}

The data used for this study consists of reviewed information on incidence of violent crimes in the Niger Delta. In specific terms, the statistics includes reported cases of kidnappings, murders and vandalism (or sabotage) in the Niger Delta region. The core Niger Delta states are the Rivers, Bayelsa and Delta; they were selected for this study because the majority of the armed militant groups that are actively terrorizing the region and creating major security challenges for the country are from these oil rich states. A statistical summary of official incidents of kidnapping, murder and vandalism recorded in the three states from the period of 2000 to 2010 is presented in brief on the table below. 


\section{Selected Incidents of Militancy in Nigeria's Niger Delta}

\begin{tabular}{|c|c|c|c|}
\hline Dates & Location & $\begin{array}{l}\text { Types of } \\
\text { Attack }\end{array}$ & Observations \\
\hline $\begin{array}{l}7^{\text {th }} \\
\text { April } \\
2000\end{array}$ & Rivers & $\begin{array}{l}\text { Armed } \\
\text { Militants } \\
\text { seized Elf } \\
\text { AquitaineOil } \\
\text { Co. }\end{array}$ & $\begin{array}{l}\text { Kidnapped } 40 \text { expatriates made up of } 10 \text { Koreans, } \\
15 \text { British and } 15 \text { French at Hostages and were all later } \\
\text { released unharmed. }\end{array}$ \\
\hline $\begin{array}{l}14^{\text {th }} \\
\text { April } \\
2000\end{array}$ & Delta & $\begin{array}{l}\text { Armed } \\
\text { Militants } \\
\text { seized Noble } \\
\text { Drilling Oil } \\
\text { Company. }\end{array}$ & $\begin{array}{l}\text { Kidnapped } 19 \text { employees contracted by the Anglo-Dutch } \\
\text { owned Shell Oil Company. Employees were later released. }\end{array}$ \\
\hline $\begin{array}{l}31^{\text {st }} \\
\text { July, } \\
2000\end{array}$ & Bayelsa & $\begin{array}{l}\text { Armed } \\
\text { Militants }\end{array}$ & $\begin{array}{l}\text { Kidnapped } 165 \text { persons at two oil drilling rigs. } \\
145 \text { were Nigerians, } 7 \text { U.S. citizens, } 5 \text { Britons, } \\
\text { and } 8 \text { Australian and Lebanese nationals. } \\
\text { All released unharmed on } 4^{\text {th }} \text { August. }\end{array}$ \\
\hline $\begin{array}{l}29^{\text {th }} \\
\text { Jan., } \\
2001\end{array}$ & Rivers & $\begin{array}{l}\text { Armed } \\
\text { Militants }\end{array}$ & $\begin{array}{l}\text { Blew up oil flow stations. } 40,000 \text { barrels of oil } \\
\text { was reported wasted per day until the situation was } \\
\text { arrested. }\end{array}$ \\
\hline $\begin{array}{l}1^{\text {st }} \\
\text { April } \\
2002\end{array}$ & Delta & $\begin{array}{l}\text { Armed } \\
\text { Militants }\end{array}$ & $\begin{array}{l}\text { Kidnapped } 10 \text { oil workers contracted to the } \\
\text { Royal Shell Oil Group out of which were 6expatriates. }\end{array}$ \\
\hline $\begin{array}{l}30^{\text {th }} \\
\text { Sept., } \\
2010\end{array}$ & Delta & $\begin{array}{l}\text { Armed } \\
\text { Militants }\end{array}$ & $\begin{array}{l}\text { Attacked Agip Oil Pipelines, shut down } 4000 \\
\text { Barrels of production each day. }\end{array}$ \\
\hline $\begin{array}{l}1^{\text {st }} \\
\text { Oct., } \\
2010\end{array}$ & Bayelsa & $\begin{array}{l}\text { Armed } \\
\text { Militants }\end{array}$ & $\begin{array}{l}\text { Attacked Agip Oil Pipeline shutting down } 4000 \text { barrels of } \\
\text { Production per day. }\end{array}$ \\
\hline $\begin{array}{l}28^{\text {th }}- \\
29^{\text {th }} \\
\text { Oct. } \\
2010\end{array}$ & $\begin{array}{l}\text { Bayelsa } \\
\text { Osiama } \\
\text { Field }\end{array}$ & $\begin{array}{l}\text { Armed } \\
\text { Militants }\end{array}$ & Sabotaged oil minor pipeline. \\
\hline
\end{tabular}

Source: Extracted from various press reports for the periods of 2000-2010

It is apparent from the table that kidnapping and violent attacks were prevalent in the areas of Rivers, Delta and Bayelsa. The occurrences of those criminal activities are distributed across Rivers, Delta and Bayelsa states respectively. In all the three states, the criminal activity of kidnapping oil workers was very intensive. Each state also has the history of vandalizing and blowing up oil infrastructural establishments. The same table revealed that while the kidnapping of oil workers intensified in all the three states under study, it also reported the history of releasing victims unharmed.

\section{DISCUSSION}

From the above table, we noticed that the armed militants' criminal activities such as kidnapping was uniformly distributed across the 'core Niger Delta states'. In all the three 
states, the criminal activities of violently blowing up oil-pipelines was prevalent [in all the geographic regions]. Looking at the geographical features of Nigeria, one would notice that the Deltaic states are in the central oil production zones when compared with the other states in the Niger Delta, and crude oil being the major economic life-blood of Nigeria's economy makes it a target of attack [as a means of expressing their frustrations on Nigeria and the Oil Companies].

The people from the core oil producing states believe that oil production and other related economic resources should bring about the growth and development of their local communities, especially those areas where crude oil is produced. However, this belief was quite the opposite, because the Nigerian government was virtually in the business of exploiting the helpless local communities. As a result, the natives of this indigenous group decided to form militia or subcultural groups against the federal government and the oil companies.

Since 2000, the militants have engaged Nigeria with enormous violence, aggression and human security challenges, especially in those oil zones, and have created general catastrophic actions of terror, kidnapping, hostage-taking and vandalism in the areas. The armed militants in the Niger Delta and other armed terrorists in the country have made security in the nation very difficult. The emergence of terror and militancy in Nigeria in recent times could be likened to a wild-fire that just spread so fast in the country with grotesque images of humiliation and fear (Ordu, 2015). From the onset, "the inability of the Nigerian government, particularly during the military era, to address the root causes of the Niger Delta agitation resulted in the proliferation of ethnic militia groups, causing the militarization of the nearly entire region. This ethnic and political unrest continued throughout the 1990s and persisted even after the establishment of democracy in 1999" (Badiora, 2015 p. 59). In January 2001, armed militants violently blew up oil flow stations and wasted 40,000 barrels of oil daily in Rivers State. In September 2010, armed militants also violently blew up the oil pipelines in Delta state and wasted 4000 barrels daily. And in October 2010, armed militants aggressively blew up the oil pipelines in Bayelsa state and wasted 4000 barrels daily as well. These oil installation damages and human hostages were systematic efforts of the militants to frustrate and humiliate the federal government and oil companies (Adams et al., 2014; Nwogwugwu et al., 2012).

Looking carefully at the above table, one would observe that human beings have become human commodities for terroristic acts of drawing government's attention for their demands in the oil zones. The militants are furious, aggressive and violence; people are frightened as government and oil companies devise strategies of repressiveness rather than developing lasting policy solutions that would appease the people and the militants. Kidnapping, hostagetaking, and destructions of oil facilities have become rampart, and Nigeria's image smeared as one of the most volatile and crime-prone countries in the world.

\section{Emergence of Militants in the Niger Delta Region of Nigeria}

Between the periods of 2000 and 2010, Nigeria experienced emergence of numerous militant groups which have created serious national and human security threats for the nation. Ethnic militias such as Movement for the Emancipation of the Niger Delta (MEND), Movement of the Sovereign State of Biafra (MOSSOB), Ethnic Ijaw Militant groups, Niger Delta Vigilante Force (NDVF) and others, have created serious national security challenges for the country. However, human beings are not born militants, but consciously choose the course of violence and aggression due to multifarious factors. Such factors include background conditions which include political, social, cultural, economic, psychological and environmental situations. Mazrui 
(2007) posited that militants cannot be efficiently dealt with unless their agitations are systematically studied and satisfied. They are organized and are strategists in projecting their demands while adopting terroristic methods to accomplish their goals.

In the Niger Delta region, each militant group has a Commander-in-Chief. Adams and Ogbonnaya (2014), citing Cesarz, Morrison and Cooke (2003), maintained that the Movement for the Emancipation of the Niger Delta (MEND) is led by Henry Okah, the Niger Delta People's Volunteer Force (NDPVF) is led by Alhaji Asari Dokubo, the Niger Delta Vigilante Force (NDVF) is pear-headed by Ateke Tom, the Bush Boys, the Martyrs Brigade and others are also in operation with notable person in society as their leaders. Adams and Ogbonnaya (2014) asserted that many of these violent groups sprang up because they receive funding, logistics, illicit arms deal, free movement of goods and services from international sources; these illegal connections enabled illicit global economy such as bunkering to flourish.

After so many years of deprivation and exclusions from fair-profit sharing of the revenue from the oil and natural gas [extracted mainly from the Niger Delta region], and a decade of environmental degradation and pollution, people turn to aggression and rebellion with violent expression of their opposition. Badiora (2015) argued that when expectation outstrips achievement-regardless of the absolute levels of economic consumption or the provision of political rights-frustration is generated, and this collective frustration turns to anger, aggression and violence. Furthermore, MEND, MOSSOB and other militant groups are behind the increase in kidnappings, bombings, interpersonal violence, politically motivated killings, and other crimes in Nigeria (Badiora, 2015). Those criminal activities occur due to frustration, anger and government's repressive behaviour. The "security of the nation is at stake with series of kidnapping activities and terroristic acts prevailing in many parts of the country" (Ordu, 2015 p. 211). As those crimes increase in the nation, the oil companies shut down production, and the Nigerian economy worsens.

\section{Root Causes of Militancy and Insecurity in the Niger Delta of Nigeria}

The activities of the militants in Nigeria, especially the Niger Delta region have created both national and human security nightmare for the country. The Niger Delta people have complained of environmental pollution, abject poverty (in midst of billion barrels of oil and natural gas reserves extracted in the region), divide and rule policy of the oil companies, air pollution, destruction of aquatic ecosystem, and soil quality alteration. The inability of the federal government of Nigeria and oil companies to systematically address the root causes of Niger Delta people's agitation have resulted in the emergence of ethnic militia groups against the government and the oil companies. Hence, we turn to discuss some of the root causes of militancy and insecurity situation in the Niger Delta [for a clearer understanding of the frustrations of the agitators].

\section{Environmental Pollution}

The 24 hours gas flares and oil spillage have become the environmental drones hunting the people of the Niger Delta region. The destructions of the Niger Delta environment weigh heavily on the glorious oil land basins in Rivers State to the deep oil wells in Bayelsa and to the core oceanic oil depots in Delta and all the core features of the natural gas floats. There exists an avalanche of literature pointing to the economic and environmental wastes in the Niger Delta region of Nigeria. Even media reports on this issue abound, especially when the natives and other inhabitants of this took the law into their hands in a bid to defend their farmlands, rivers (fish ponds) and their general ecosystems by forming subcultural groups as actionprone militants. Research shows that the region of "Niger Delta is in the throes of becoming an 
environmental wastebasket" (Nwogwugwu et al., 2012 p.26). This environmental destruction has caused indescribable and irredeemable ecological devastation of the Niger Delta. Environmental pollution particularly has quarantined the Niger Delta region (Azaiki, 2007). The natural air, aquatic ecosystem and soil quality are ruined by gas flares and oil spillage. The strategic challenge facing Nigeria is how to cure the destructive damages already done to the region, or reparations for many years of negligence, abandonment and repressiveness. The nation's notorious negligence have exhumed all types of militant groups, invoked all manners of aggressions, and flares violence in all Niger Delta areas (Okaba, 2005).

\section{Poverty and Social Exclusion}

While Nigerian government and the Oil companies exploited the Niger Delta, the people's subsistence means of economic opportunity was destroyed. The economic dependency of the people of Niger Delta was their farmlands, fishponds and rivers. This means of economic dependence was radically altered when the oil companies spilled crude oil on their farmlands, rivers and fishponds, thereby rending their economic means of survival lifeless and without compensations. As a result, the people that were once self-reliant and productive [in their selfemployed farmlands and rivers] hit the worst economic disaster (Okonta \& Oronto, 2001). Thus, frustration, poverty and misery set in and consequently acted out through militancy and other criminalities as an escape route. Poverty is one of the driving forces behind the rapid increases in violence and aggression in the Niger Delta region. This made Adams and Ogbonnaya (2014 p. 23) to posit that "internal act of terror and violence is sometimes a deliberate choice", that is geared towards the accomplishment of common goals and/or objectives. The sting of destitution that most people lived in their communities draw them into militant groups that promised to lift them out of abject poverty into prosperous life.

A greater majority of Nigerians are living in absolute poverty and social exclusions, and if any one promises to bring about changes in their poverty-stricken situations, people are usually compelled to follow the terrain of hopeful good life either through fair means or foul. With this in mind, members of the militants are committed to fight for what they strongly believe is their right to defend their lives and property. In Nigeria, according to Agboti and Nnam (2015), various forms of crimes such as political thugs, robbery, arson, murder, kidnapping and militancy can be explained and understood within the purview of 'deprivation-discontent' philosophy which is embedded in different types of social exclusion.

Ikoh (2011) posited that long years of negligent by successive government to develop the Niger Delta region and the failure of multinational oil companies to integrate and transform the oil-producing communities into prosperous communities led to the feeling of deprivation and sequent crises that made militancy and kidnapping pervasive crimes in Nigeria today. Agboti and

Nnam (2015) explained that many Nigerians (people of Niger Delta precisely) have suffered exclusion of different kinds in their day-to-day activities. They are frequently abused and neglected, politically battered and abandoned, and their constitutional rights denied with impunity. When people are relatively deprived of essential goods and services as well as excluded from their natural resources, frustration and depression will invariably ensue and consequently lead to acting out of their discontentment and aggression through all means, including crime, violence and militancy. Specifically, the duo added, that somewhat doused ugly incidence of militancy in the Niger Delta and kidnapping in the southeast regions of 
Nigeria is an indirect explanation and/or a backlash of the widespread social exclusion in those regions.

\section{Unemployment and Underemployment}

The existence of oil, oil companies and other mineral reserves in the Niger Delta would have served as recourse during economic difficulties, but rather they appear to invoke curses in the region, as the people are displaced in their local farming due to oil spills and systematic destruction of their farmlands and aquatic environment. As a result of displacement, unemployment and underemployment became a serious plague in this region. The oil companies adopted employment discrimination against the youths of Niger Delta, thereby fostering youths' involvement in violence and hatred against the federal government (Ejibunu, 2007; Okonta \& Oronta, 2001). Employment discrimination furthers youths' frustration and involvement in crime and violence. When the political elite marginalize the lower class, it manifests in "unemployment, poverty, hunger and deprivations" (Ubhenin \& Enabunene, 2011 p. 56).

Nigeria has a historical problem as regards mismanagement of resources and corruption. Today, the problem induced by decades of mismanagement of the oil revenue and other natural resources accrued from the Niger Delta negatively affects many lives and property in the nation. As a result, militants kill, humiliate, destroy oil installations worth billions of naira, and create perpetual fear of insecurity in the oil zones. They perpetrate vandalism, bombard oil infrastructure and social amenities, kidnapping and importunate demands for ransom with threatening menace and aggravated violence.

In fact, the high rate of unemployment among youths in Nigeria is one of the causes of kidnapping in the country (Diara, 2010; Ejibunu, 2007). Another research stipulated that "the meteoric rise in unemployment, poverty, social exclusion and weak or dysfunctional social structures (both formal and informal) has exacerbated the crime problem in Nigeria" (Nnam, Agboti \& Otu, 2013 p. 80). The upsurge of unemployment and underemployment in Nigeria precipitate some people into kidnapping to eke out a living and, or as a coping mechanism to the vicissitudes of idle life. This claim is in tandem with the maxim of 'an idle mind is a devil's workshop'. Many unemployed and underemployed persons may refuse to accept a bleak future or be classified as the dregs of humanity because of the sorry-state of their socioeconomic backgrounds in the society. Confronted with unending excruciating pains of unemployment, certain individuals resort to kidnaping as an escape route and easy way to a desired ends (Nnam \& Otu, 2015).

The pervasive influence of kidnapping in Nigeria is directly linked to the unacceptable rate of unemployment in the country (Adibe, 2012). Unemployment or underemployment gives rise to social problems like militancy and general insecurity in a country where it holds sway. The inability of the oil companies and federal government of Nigeria to improve the environmental and social structure and political economy of the people of Niger Delta implies insensitivity of the former to the plight of the latter. This incapacitating condition consciously or unconsciously induce revolutionary action so as to restore social justice and attenuate the systemic environment harm meted out to the inhabitants of Niger Delta. Little wonder therefore that many youths in this region form or join subcultural associations as powerful medium through which the attentions of the oil companies and government could be drawn to their problems in the Niger Delta. This is done through the criminal means of militancy, vandalism, kidnapping, oil-pipeline sabotage and terrorism. Corroborating this view, Ishaya (2010) attested in his media report that the Movement for the Emancipation of the Niger Delta (MEND) initially indulged in kidnapping and militancy to draw national and international 
attention to the plight of the people of Niger Delta. Akpan (2010) reiterated that early versions of kidnapping and uprisings in Niger Delta region of Nigeria were believed to be a part of the wider liberation call by MEND and other militias for the development of the South-South region. Indeed, widespread of criminal activities was part of the outcome of a confrontation between MEND and oil interest groups and/or the Federal Government of Nigeria.

\section{Implications of Militancy and Insecurity in the Niger Delta Region of Nigeria}

The ongoing discussion about militant activities in the Niger Delta region has many ugly flavors with a common theme of 'unequal distribution of the revenue generated from the crude oil' (Ogbonnaya et al., 2015; Nwogwugwu et al., 2012; Badiora, 2015). In fact, the unequal distribution of both political and economic power has also contributed to the negligence of the people of Niger Delta. This negligence has led to the ideologies associated with the formation of radical violent groups with their manifestations in militancy, kidnapping and other heinous crimes. The violent acts perpetrated by militants are synonymous with terrorism; a situation that Okoli and Iortyer (2014 p. 39) argued that it "is the biggest threat to global peace and stability in this contemporary times." The acts of terror and aggression by the militants have had serious implications on Nigeria in the areas of politics, economy, and social life. The lives and property of militants themselves, their family members and other law-abiding citizens have been destroyed as militants indiscriminately and irrationally carry out their inhuman operations in both the interior and hinterlands of the Niger Delta.

The ability of a nation to stand firm as one indivisible entity with sense of belonging is when the politicians are able to lead the people into a strong and secured state, not a failed state. When conflict, anarchy, aggression and violence pervade a nation due to injustice, mischievousness and mistrust, the nation approaches a violent breakage, if grievances continue unabated. Bloomfield (2006 p. 5), cited in Ubhenin and Enabunene (2011), admitted that "violent conflict has by its nature a degree of confused, emotional and apparently nonrational thinking and behaviour in its workings". Dissatisfaction with the status quo has the ability to lead the militants into terror, aggression and kidnapping. Moreover, these activities have proven effective in bringing about change by forcing the state compliance (Cinar, 2009; Kimiebi, 2010).

The incessant commission of militancy in Nigeria fosters constant national and human security threat; it does not guarantee public safety and peaceful coexistence. Militancy promotes continuous violent attacks on oil infrastructure, public buildings and also creates serious economic consequences. The negligence of the Nigerian government and the oil companies culminating in their failure or indifferent and lackadaisical attitudes towards the grievances and maltreatments of the Niger Delta further paves way for the emergence of many more violent militant groups with its resultant effects on persistent criminal life-course and upsurge in criminal trajectories in this region. Such negligence can lead to confusion, conflict, and war. It brings about a breakdown of the economic and social life of the people. However, violence among the militant groups manifest in economic disintegration and wanton destruction of lives and property in the oil zones.

The increased militarization of inhabitants of the Niger Delta oil zones is as a result of frequent attacks on both Nigerian civilians and foreign nationals in the country, thereby creating an ugly image of Nigeria in the global village. As the incidence of kidnapping of expatriates becomes rampant, the external world equally becomes increasingly aware of Nigeria's insecurity situation. Militant organizations are responsible for most of the recent kidnapping of 
expatriates, destruction of oil pipelines, and significant illegal acts of aggressions and violence in the country, especially in the oil zones (Mazrui, 2007; Kimiebi, 2010). These acts expose the Nigeria's security measures as very weak and fragile. The weakness of public institutions and state security apparatus in maintaining at least middle-range peace measures fosters distrust and lack of confidence, and proliferation of militant groups, as well as spurs more youths into militancy and other criminalities. This is because the state security agencies have failed to decisively deploy or devise proactive peace-restoration measures that would disengage the militants from most of their strategic planning methods.

In reaction to the widespread impoverishment of the Niger Delta community, glaring security failure and/or criminal negligence of both state and non-state actors to improve the living standard of inhabitants of this region, crime and violence, though regrettably, become coping mechanisms and adjustment patterns. Consequently, "people are afraid to walk on the streets at night" (Oviasogie, 2013 p. 22), to avoid falling prey to militants and kidnappers. These criminals take advantage of the weak security network in Nigeria (especially in the Niger Delta areas) to radicalize more youths, and in so doing, enlist them into their various criminal subcultures with a view to systematically gain advantage over the state security personnel in their combat operations (Adams \& Ogbonnaya, 2014). Having achieved this, the state security agents are placed in the dilemma of compromise and tacit capitulation as they have no option but to submit to the demands of the militant groups.

The above implications, combined with weak governance, unbridled corruption, unmitigated unemployment and underemployment, social injustices and increased human rights violations, have contributed to the widespread dissatisfaction among the Niger Delta people. These have contributed tremendously to the radicalization of the youths into militant groups and increase in their reactionary terroristic acts of violence and aggression (Ogbonnaya \& Stiegler, 2014). Citing Blau and Blau (1982), Siegel (2008) affirmed that people who feel deprived because of their race or economic class eventually develop a sense of injustice and discontent. The less fortunate among this class of people will begin to distrust the society that has nurtured social inequality and obstructed their chances of progressing by legitimate means. Agboti and Nnam (2015) stated that individuals under exclusion of any kind will certainly feel both deprived and cheated when they compare their socioeconomic disadvantages to those of the affluent, and a consequence may resort to retaliatory crimes.

\section{Ways Out of Militancy, Violence and Aggression in the Niger Delta Region of Nigeria}

The presence of military officers in the oil producing areas has the tendency of provoking and instigating further violence and aggression. According to Bloomfield (2006) as recorded in Ubhenin and Enabunene (2011), violence and aggression by their nature inhibit certain degrees of confusion, emotional, irrational thoughts and conflict. Instead of violent approach, the federal government of Nigeria should endeavour to see the values that are in the contents of the nonviolent stance of the Niger Delta people. Therefore, it is incumbent on the federal government to establish institutions or agencies that would address the security challenges in the oil region by providing lasting solutions [to the problem of militancy, violence and aggression in Niger Delta region] for national peace and development.

The establishments of the Oil Mineral Producing Areas Development Commission (OMPADEC), the Niger Delta Development Commission (NDDC) and the Ministry of Niger Delta (MND) by the previous administrations in Nigeria are pathway to ameliorating the plight of the southsouth geographical zone of the country. Although these agencies, to an extent, have addressed the problem of the people of Niger Delta, their efforts seem to be a palliative rather than 
panacea. In other words, their strategic approaches did not or are yet to halt the negative destructive pictures of the land and rivers, and the exploitative impressions created by the government and the oil companies in the affected communities (Akanni, 2014). Hence, the people's rebelliousness and militant group formations persisted. Therefore, the government should consider allowing the people to be the major players in the production, marketing, and distribution of the oil and natural gas from their own land or communities.

The federal government of Nigeria has in the past instituted an amnesty for the militants in an effort to appease them to lay down their arms and end hostilities against the people and the government. Even at this proposition, the government has maintained repressive measures as evident in the undemocratic deployment of the Nigerian military (army, navy and air force) and some paramilitary personnel at the major oil producing areas as ways of influencing and silencing the militants. Ubhenin and Enabunene (2011) pointed out that, despite the federal government repressive measures, the militants have been successful in kidnapping not only the foreign oil workers, but also other residents of the Niger Delta region. This act continues unabated because the militants rather considered their act as liberation struggle. No wonder some observers like Akpan (2010) and Badiora (2015) reported that the early kidnapping incidents in the Niger Delta region, particularly Rivers State are believed to have been part of a wider liberation call by the Movement for the Emancipation of the Niger Delta.

The Niger Delta people feel disenchanted with the exploitation of their mineral resources with minimal profits or dividends given to them, the host community. The unequal distribution of resources would continue to invoke criminality in the Niger Delta, until the federal government of Nigeria ends their dependency on oil and natural gas from the Niger Delta region. Therefore, it is essential that Nigeria begins to devise other strategic means of economic dependency by ending a decade of oil reliance. Nigeria should take cue from the Civilized Western Societies which are steadily seeking ways to end their foreign energy dependency by manufacturing electric cars and promoting solar energy systems. Indeed, Nigeria should think towards that direction rather than depending solely on oil derived from Niger Delta region. This will help to jettison the environmental and social harm/pressures on both material and human resources in this part of the country.

\section{CONCLUSION}

Nigeria has had various security challenges for decades. Recently, the havoc and security challenges caused by various militant groups in the Niger Delta region of Nigeria have taken a horrendous modus operandi with devastating effects. According to Alaibe (2010), militancy in the Niger Delta had virtually crippled Nigeria's economy. The inability of the government and its security agencies to adequately address the demands of the people and aggression against the federal government and oil companies have heightened the security problem in the country.

Kidnapping, vandalism, aggression and violence against oil workers in Nigeria have remained the most serious contemporary crimes ravaging the nation, especially in the Niger Delta areas. Some of the underlying causes of militancy and insecurity in this part of the country are poverty, social exclusion, unemployment, environmental degradation, and lack of infrastructural development. The government should formulate and effectively implement policies and programmes capable of tackling the main causes and spread of the social turmoil in the oil states of Delta, Bayelsa and Rivers. 
The Nigerian government should establish a system of social inclusion to counter the prevailing social exclusion in the Niger Delta. This will enable the people of this region to be deeply involved in their economic, social and political affairs. The attainment of this goal requires a situation whereby the significant others among the natives or indigenous stakeholders become major players in the production, marketing and distribution of crude oil in the country. It should be clear that no other regions of Nigeria is affected in environmental pollutions and economic crises as the Niger Delta people, and they contribute immensely to the economic growth and development of Nigerian through foreign exchange earnings and revenue generations.

\section{References}

Adams, D. \& Ogbonnaya, U. M. (2014). Ethnic and regional violence in Nigeria: Implications for national security. Journal of Politics and Law, 7(3), 20-34.

Adegbami, A. (2013). Insecurity: A threat to human existence and economic development in Nigeria Public Policy and Administration Research, 3 (6), 8-13.

Adibe, J. (2012). Pervasive kidnapping in Nigeria: Symptom of a failing state. Retrieved from http://www.hollerafrica.com/showarticle.php?artld=304\&catled=1. Accessed 3rd March, 2016.

Agboti, C. I. \& Nnam, M. U. (2015). An assessment of the relationship between crime and social exclusion in Nigeria. International Journal of Research in Arts and Social Sciences, 8 (1), 157-164.

Akanni, A. A. (2014). History of terrorism, youth psychology and unemployment in Nigeria. Journal of Pan African Studies, 7(3), 65-76.

Ake, C. (1981). A political economy of Africa, Akure: Longman.

Akpan, N. S. (2010). Kidnapping in Nigeria's Niger Delta: An exploratory study. Journal of Social Sciences, 24(1), 33-42.

Alaibe, T. (2010). Presidential amnesty programme: One year after. Champion Newspapers.

Retrieved from http://www.champion.com.ng/displaycontent.asp?pid=1302. Accessed 7th July, 2016.

Azaiki, S. (2007). Inequities in Nigerian politics. Ibadan: Y-Books.

Badiora, A.I. (2015). Regional differences and developmental implications of security challenges in Nigeria. African Security Review, 24(1), 55-62.

Bailey, K.D. (1982). Methods of social research (2nd. ed.). New York: Macmillan Publishing.

Cinar, B. (2009). The root causes of terrorism. METU Studies in Development, 36(6), 93-119.

Diara, B.C.(2010). Kidnapping for ransom as a revolutionary effect of capitalism in Africa. International Journal of Research in Arts and Social Sciences, 2, 49-58.

Ejibunu, H.T. (2007). Nigeria's Niger Delta crisis: Root causes of peacelessness. Retrieved from http.//www.aspr.ac.at/epu/research/rp0707.pdf. Accessed 7th July, 2016.

Erikson, K. (1966). Wayward puritans: A study in the sociology of deviance. New York: Wiley.

Ikoh, M.U. (2011). Criminal victimisation in Nigeria: Pattern and trend. In E. E. O. Alemika \& I. C. Chukwuma (Eds.), Crime victimisation, safety and policing in Nigeria (pp. 41-100). Lagos: Malthouse Press.

Ishaya, I. (2010). The journey into the arms of the gangster. Newswatch, July, pp. 14-21.

Kimiebi, I. E. (2010). Oil militancy and political opportunities in Niger Delta. Retrieved from http://kimiebi.Blogspot.com. Accessed 7th July, 2016.

Klegon, D. (1981). The social scientists as historian: How important is it to look black? In T. C.Wagenaar (Ed.), Readiness for social research. Belmont, California: Wadsworth.

Mazrui, A. A. (2007). Towards understanding the causes of terrorism: The culture, the mission, The motive and the target. Retrieved from http://www.unglobalsecurity.org// pdf/mazrui. pdf. Accessed 7th July, 2016.

Nnam, M. U., Agboti, C. I. \& Otu, M. S. (2013). Inadequate motivation as a reason for police officers' ineffectiveness in policing contemporary Nigeria. South South Journal of Culture and Development, 15(2), 67-86. 
Nnam, M. U.\& Otu, M. S. (2015). Predictors and incidence of kidnapping in contemporary Nigeria: A sociocriminological analysis. International Journal of Recent Research in Social Sciences and Humanities, 2(1), 38-43.

Nwogwugwu, N., Alao, O. E. \& Egwuonwu, C. (2012). Militancy and insecurity in the Niger Delta: Impact on the inflow of foreign direct investment in Nigeria. Kuwait Chapter of Arabian Journal of Business and Management Review, 2(1), 23-37.

Ogbonnaya, K. O. \& Stiegler, N. (2014). Terrorism in Nigeria African Security Review, 23(2),

145-160

Okaba, B. O. (2005). Petroleum industry and the paradox of rural poverty in the Niger Delta. Benin City: Ethiope Publishing.

Okoli, A. C. \& Iortyer, P. (2014). Terrorism and humanitarian crisis in Nigeria: Insights from

Boko Haram insurgency Global Journal of Human Social Science and Political Science, 14(1), 39-50.

Okonta, I \& Oronta, D. (2001). Where vultures feast, forty years of oil in the Niger Delta. Ibadan: Kraft Books.

Ordu, G. E. O. (2015). Insecurity and Islamic fundamentalism in Nigeria: A nation at brink with Boko Haram. International Journal of Humanities, Social Sciences and Education, 2 (5), 210-221

Oviasogie, F.O. (2013). State failure, terrorism and global security: An appraisal of the Boko Haram insurgency in northern Nigeria. Journal of Sustainable Society, 2(1), 20-30.

Piven, F. F. \& Cloward, R. (1971). Regulating the poor: The functions of public welfare. New York: Random House, Vintage.

Siegel, L. J. (2008). Criminology: The core (3rd ed.). Belmont, California: Thomas Higher Education.

Thio, A. (2004). Deviant behavior (7th ed.). Boston, MA: Pearson Education.

Ubhenin, O. E. \& Enabunene, S. (2011). Youth restiveness and credible alternatives to violence in Nigeria. Journal of Human Security, 7(1), 53-67

Williamson, J. B., Karp, D. A. \& Dalphin, J. R. (1977). The research craft: An introduction to social science methods. Boston: Little Brown. 